Скрипчук П. М. [1; ORCID ID: 0000-0002-2835-4711], д.е.н., професор, Шпак Г. М. [2; ORCID ID: 0000-0002-8588-441X], K.e.H.,

Трохлюк Т. М. [3; ORCID ID: 0000-0002-8336-8665], к.e.H.

${ }^{1}$ Національний університет водного господарства та природокористування, м. Рівне ${ }^{2} B C П$ «Рівненський технічний фаховий коледж» НУВГП, м. Рівне ${ }^{3} B C П$ «Березнівський лісотехнічний фаховий коледж» НУВГП, м. Березне,

Рівненської обл.

\title{
ПОВОДЖЕННЯ 3 ПОБІЧНИМИ ПРОДУКТАМИ В ЕКОНОМІЦІ: БІСНЕС-ПРОЦЕСИ У КОНТЕКСТІ ЄВРОІНТЕГРАЦІї
}

Кращі світові практики та інституції (ООН, ЮНІДО та ЮНЕП) вважають, що ресурсно-ефективне та більш чисте виробництво це шлях до циркулярної економіки й поводження 3 відходами. Гармонізація законів та стандартів в Україні передбачає використання превентивних стратегій поводження 3 всіма видами відходів, які підвищують ефективність економіки, формують соціальну й екологічну значимість. Перспективними для України є: сортування відходів 3 наступною їх переробкою; формування онлайн-платформ збору й логістики відходів; окремі види поводження 3 токсичними, медичними відходами; не допущення спалювання відходів та захоронення лише частки відходів яких не можливо переробити. Одним із варіантів діджиталізації сфери поводження 3 відходами може бути інструмент - інформаційнокомунікативні платформи в регіонах (громадах) у методології на рівні світу як от Платформа зеленого зростання.

Ключові слова: тверді побутові відходи; поводження з побічними продуктами; економічна ефективність; бізнес-процеси; євроінтеграція.

Постановка наукової проблеми та їі значення. В усьому світі, i особливо в Україні, дуже гостро стоїть еколого-економічна й соціальна проблема, пов'язана з поводженням щодо відходів. Очікується, що у 2050 році населення буде генерувати більш як 13,1 млрд тонн відходів у зв'язку з підвищенням рівня життя i доходів. Це на $20 \%$ більше ніж за останні 10 років при тому, що лише $25 \%$ всіх відходів сьогодні утилізуються або регенеруються. Розрахунки, здійснені в межах проєкту «Бачення - 2050» Всесвітньої бізнес-ради із сталого розвитку, В якому брали участь 
29 найкрупніших компаній-членів, представники урядових структур та експерти, доводять, що традиційний шлях розвитку світової економіки за «звичайною бізнес-стратегією» вимагатиме споживання природних ресурсів для забезпечення зростаючого населення Землі у 2050 році в обсязі, еквівалентному 2,3 сьогоднішнього обсягу ресурсів планети [1]. Тому такі світові інституції, як ЮНІДО та ЮНЕП вважають, що ресурсно-ефективне та більш чисте виробництво - це шлях до підвищення ефективності виробництва, що передбачає використання превентивних стратегій управління, які підвищують продуктивне використання природних ресурсів, мінімізують створення відходів та емісій і базуються на використанні інструментарію більш чистого виробництва: ефективність виробництва - це оптимізація продуктивного використання природних ресурсів (матеріалів, енергії, води); екологічне управління - це мінімізація впливу на навколишнє природне середовище через зменшення відходів та емісій; людський розвиток - мінімізація ризиків для людей та спільнот і підтримка їх розвитку тощо.

Щорічно роль зеленого інвестування на світових ринках капіталу зростає, що підтверджує передусім зростання обсягів фінансових ресурсів, спрямованих у «зелені» проєкти. За даними Форуму соціального інвестування США, приблизно 11\% прибутків великі корпорації витрачають на стале інвестування, в Європі ця цифра становить приблизно $17 \%$, в тому числі й на нові технології переробки відходів [1; 2].

Огляд наукових джерел. Питання поводження 3 відходами регламентується в Законі України «Про відходи», в якому визначено правові, організаційні та економічні засади діяльності, пов'язаної із запобіганням й зменшенням обсягів утворення відходів, їх сортуванням, обробленням, утилізацією, видаленням та захороненням тощо [6]. Зокрема, особливості поводження 3 відходами на різних рівнях розглядали вітчизняні вчені: Близнюк А. М., Бєляєва С.С., Горобець О. В., Губанова О. Р., Ігнатенко О.П., Вяткін П.С., Орлова Т. О., Хижнякова Н. О., Шунтова С. Г., Повний С. М. та ін. Окремі аспекти управління відходами висвітлені в публікаціях таких вітчизняних дослідників, як Андрейченко А. В., Дериколенко О. М., Кержаков В.І., Довга Т. М., Попова О. Ю., Руденко О. В., Шулаєва Ю. Е. Зарубіжні вчені розглядали управління відходами в контексті циркулярної економіки, зокрема Б. Майс, Кян Йі, Танг Ксяо-Ян, Гейсер К., ВенХонг Жанг та ін. 
Економічні аспекти проблем європейської інтеграції України вивчають: Л.Гальперін, О.Гладський, І. Єгоров, С. Науменко, М. Калина, О.Ковальова, В. Онищенко, В. Сіденко, О. Шнирков, які розглядають різні аспекти проблеми відповідності української економіки європейським вимогам та напрямки необхідних робіт 3 гармонізації законодавчо-нормативних документів. Принципи, проблеми та перспективи наближення правової системи України до права ЄC, необхідність імплементації Україною міжнародних угод вивчають В. Буткевич, С. Войтович, В. Денисов, А. Довгерт, Л. Заблоцька, В. Кисіль, М. Козюбра, В. Крушинський, С. Шевчук, Ю. Шемшученко, Т. Шинкаренко, О. Шнирков та ін. [3].

Постановка наукової проблеми. Розробка теоретикометодологічних основ і завдань для України у сфері європейської інтеграції, ресурсо-, енергоефективності, поводжені 3 відходами передбачає розробку бізнес-процесів на різних рівнях як обов'язкових складових конкурентоспроможності в усіх галузях економіки. Водночас намагання бізнесу досягти зближення 3 євростандартами у різних галузях економіки досить часто зустрічає труднощі щодо їх повноцінного впровадження, які постають із незавершеності економічних реформ в Україні та несформованості відповідного економіко-правового середовища й не задовільних темпів адаптації законодавчо-нормативних документів.

Результати досліджень та їх обговорення. Система поводження з відходами в Україні знаходиться на рівні найбідніших країн. За роки незалежності кількість твердих побутових відходів (ТПВ) в Україні збільшилась на 25\%, але підходи до поводження 3 відходами принципово не змінились. Як і раніше, майже всі ТПВ вивозяться для захоронення на полігони побутових відходів та часто й на несанкціоновані звалища. Звалища ТПВ потребують значних площ й призводять до серйозних екологічних проблем та негативного впливу на здоров'я людини.

Підписання у 2014 р. Угоди про асоціацію 3 Європейським Союзом зобов'язало Україну наблизити своє законодавство у сфері поводження з відходами до законодавства ЄС. Україні необхідно повністю імплементувати положення Директиви 2008/98/ЄС Європейського Парламенту та Ради від 19 листопада 2008 р. «Про відходи..» [2]. Директива запроваджує п'ятирівневу ієрархію поводження з відходами:

1) попередження виникнення відходів (найкращий варіант через низку інструментів: екологічний аудит, більш чисті технології, кращі практики, системи екологічного управління тощо);

2) повторне використання сортованих відходів; 
3) економічно доцільна переробка відходів (вторинних ресурсів) (склобою, макулатури, металу, пластику);

4) впровадження заборони на спалювання відходів;

5) захоронення на полігоні тих відходів, які не можна переробити.

Основні кращі практики поводження з ТПВ в ЄС відповідають положенням:

- селективний збір ТПВ з наступним їх сортуванням (за даними інтернет-джерел в Японії у 2021 році вже сортують 32 види відходів);

- роздільний збір великогабаритних відходів за окремими графіками й логістикою;

- роздільний збір небезпечних відходів (батарейок, акумуляторів, медичних відходів, побутової й промислової хімії тощо);

- окремі проблеми пов'язані з утворенням токсичних речовин після спалювання ТПВ;

- захоронення частини відходів, які не можна переробити, на спеціальних полігонах, що унеможливлює забруднення навколишнього природного середовища.

Основні практики країн ЄС наступні:

1. Впроваджено концепцію «циркулярної економіки», за якою сміття стає сировиною для виробництва. Застосовуються біотехнології, що дозволяють розщепляти пластик. Так забезпечується замкнений цикл бізнес-процесів - відходи від одного продукту використовуються для створення іншого.

2. Застосовується комплекс бізнес-процесів 3 переробки органічних відходів на компости та біодобрива.

3. Працює система бізнес-процесів повернення коштів за тару. Покупцям відшкодовують гроші після того, як вони повернуть використаний посуд. Кошти від цієї заставної ціни розподіляються так: 85\% - на організацію збору тари, 15\% - на переробку.

4. Спеціальне законодавство допомогло закрити нелегальні сміттєзвалища, а економічні інструменти (штрафи) призвели до сортування відходів.

5. Діджиталізація бізнес-процесів сфери поводження 3 відходами. Наприклад, у Франції на кожному сміттєвому баку $є$ мікрочіп, який автоматично фіксує час наповнення і час вивезення сміття. Сміттєвози обладнано зчитувальними пристроями та бортовими комп'ютерами, які автоматично зчитують інформацію та надають змогу організувати оптимальні маршрути машин [2].

Тому попередження утворення відходів $€$ найпростішим та 
найбажанішим способом поводження 3 відходами та відповідає Директиві 2008/98/ЄС про відходи, що має відбуватися в Україні шляхом:

- зменшення кількості відходів;

- зменшення несприятливого впливу відходів на навколишнє природне середовище і здоров'я людини та зменшення вмісту шкідливих речовин у матеріалах та продуктах;

- впровадження Національної стратегії управління відходами в Україні до 2030 року, в якій передбачити конкретні заходи щодо зменшення використання пластикових виробів, рівня повторного їх використання та переробки;

- запровадження роздільного збору пластику всіх видів;

- стимулювання бізнесу до виробництва екологічно безпечних товарів як альтернативи пластиковим виробам;

- запровадження механізму «забруднювач платить», який забезпечить покриття витрат на управління пластиковими відходами;

- інформування населення про шкоду пластикових виробів, заохочення до зменшення їхнього споживання;

- створення мережі центрів запровадження більш чистих виробництв, кращих практик й бізнес-процесів для мінімізації обсягів утворення відходів, прийняття нормативно-правових актів щодо запровадження екодизайну товарів для споживання, які довше функціонуватимуть та будуть більш пристосованими до повторного використання чи утилізації, у тому числі шляхом перероблення, зменшення обсягів використання первинної сировини (табл. 1);

Таблиця 1

Підходи до системи поводження з відходами залежно від рівня доходів населення, \%

\begin{tabular}{|c|c|c|c|c|c|}
\hline $\begin{array}{c}\text { Рівень } \\
\text { доходів } \\
\text { населення }\end{array}$ & $\begin{array}{c}\text { Захоронення } \\
\text { на полігонах } \\
\text { всіх типів }\end{array}$ & $\begin{array}{c}\text { Компосту- } \\
\text { вання }\end{array}$ & Рециклінг & $\begin{array}{c}\text { Спалювання твердих } \\
\text { побутових відходів в } \\
\text { теплоелектроцентралях }\end{array}$ & Iнше \\
\hline Високий & 44 & 11 & 22 & 21 & 2 \\
\hline Низький & 72 & 2 & 0.5 & 1.3 & 24 \\
\hline Україна & 98 & $\begin{array}{c}\text { Процес } \\
\text { відбувається } \\
\text { у 4-х містах } \\
\text { на окремих } \\
\text { майданчиках }\end{array}$ & 0 & 1.0 & 1.0 \\
\hline
\end{tabular}

Джерело: розраховано за даними статистики 
- впровадження Закону України «Про енергетичну ефективність». У межах Протоколу про приєднання до Договору про заснування Енергетичного Співтовариства, Україна впроваджує систему енергетичного маркування енергоспоживчих продуктів та встановлення вимог з екодизайну відповідно до оновленого законодавства ЄС;

- запровадження економічних механізмів та інструментів, що стимулюватимуть зменшення кількості утворюваних відходів. Наприклад, податок чи заборону на виробництво поліетиленових пакетиків, пластикових одноразових ємностей та посуду, надавати преференції для виробників екологічно чистого упакування для споживчих товарів (табл. 2).

Особливістю європейської стандартизації $€$ своєрідний компроміс між двома підходами до стандартів: з точки зору якості навколишнього природного середовища для людини і 3 позиції мінімальних викидів, пов'язаних 3 найкращими доступними технологіями. Методологічний підхід до організації бізнес-процесів на різних рівнях між цими підходами переходить на технічний рівень. Тому стандарт описує бізнес-процеси найбільш доступної технології. Звідси особливості гармонізації, адаптації, імплементації законодавчо-нормативної бази та організації ії впровадження в Україні наступні:

Таблиця 2

Коефіцієнт утилізації відходів за регіонами України

\begin{tabular}{|l|c|c|c|c|c|}
\hline & 2010 & 2012 & 2014 & 2016 & $\begin{array}{c}\text { За } \\
\text { останні } \\
\text { роки }\end{array}$ \\
\hline Україна & 0,35 & 0,32 & 0,31 & 0,29 & 0,29 \\
\hline $\begin{array}{l}\text { Рівненська } \\
\text { область }\end{array}$ & 0,18 & 0,13 & 0,07 & 0,09 & 0,09 \\
\hline Київська & 0,44 & 0,19 & 0,07 & 0,03 & 0,03 \\
\hline Львівська & 0,02 & 0,05 & 0,16 & 0,17 & 0,17 \\
\hline
\end{tabular}

Джерело: розраховано за даними статистики

- для кожної галузі виробництва визначаються власні найбільш доступні технології та бізнес-процеси, що їх реалізують, які постійно удосконалюються;

- запровадження більш чистих технологій, створення консорціумів та альянсів українських підприємств 3 потужними компаніями країн ЄС;

- поширення інформації щодо інвестиційних потреб та можливостей в українській економіці, надання інформаційно- 
методичної та правової підтримки залученню інвестицій з країн ЄC в екологічні бізнеси;

- запровадження сучасних форм міжнародного спільного фінансування стратегічних інвестиційних проєктів;

- ресурсо- та енергозбереження, розбудова альтернативної енергетики;

- суспільна ініціатива за відповідальність виробника щодо повного «життєвого» циклу продукції та вплив ії відходів на навколишнє природне середовище;

- створення стимулів для компаній щодо відповідальності за весь «життєвий» цикл поводження з відходами (за таких умов бізнес-процеси з передачі тари (упаковки) виходять на певний час з-під контролю бізнесу i, повертаючись, вторинна сировина потребує досконалих перевірок у вхідних бізнес-процесах знову тієї ж тари чи упаковки);

- перенесення акценту з платежів (штрафів) за забруднення (кінець технологічного процесу), продукцію і відходи на платежі на вхідні фактори виробництва, особливо платежі, стимулюючі енерго-, матеріало-, водо- і природозбереження;

- модернізувати законодавчу базу в галузі стандартизації, метрологіі, сертифікації, якості, державного нагляду за ринком відповідно до вимог СОТ та ЄС на основі вивчення сучасного європейського досвіду та світової практики;

- впроваджувати європейські та міжнародні стандарти за рангом пріоритетності й соціо-еколого-економічної значимості для держави;

- удосконалити сутність і форми роботи із адаптації технічного законодавства та нормативної бази найперше у галузі екологічних стандартизації і сертифікації, оскільки характеристики і тенденції якості продукції і НПС постійно змінюються, що потребує використання нових знань;

- оптимізувати інфраструктуру системи технічного регулювання відповідно до потреб економіки та інтересів споживачів.

Такі методологічні підходи є першочерговим завданням для України у сфері європейської інтеграції щодо поводження 3 відходами та енергоефективності, як обов'язкових складових конкурентоспроможності у всіх галузях економіки. Звідси пропозиції щодо гармонізації законодавчо-нормативних документів в галузі раціонального природокористування необхідно розглядати у двох аспектах: довгостроковому i короткостроковому. Довгостроковий аспект концепції пов'язаний 3 прагненням сформувати в перспективі теоретично 
обґрунтований і практично ефективний механізм інтерналізації екстернальних витрат, а також забезпечення екологічно безпечного і економічно доцільного розвитку. Короткостроковий аспект покликаний закріпити в законодавчій та нормативній формі міжнародний досвід екологізації економіки країни з метою збереження навколишнього природного середовища від негативного антропогенного впливу.

Висновки. Проведено системне обґрунтування інструментарію, особливостей адаптації законодавчо-нормативної бази в Україні щодо поводження з відходами. Аргументовано, що першочерговими кроками щодо поліпшення практичних результатів у сфері євроінтеграції 3 питань поводження 3 відходами мають стати довгострокова концепція екологізації економіки та перехід підприємств на найкращі доступні технології. Одним із варіантів діджиталізації сфери поводження з відходами може бути інструмент - інформаційно-комунікативні платформи в регіонах (громадах) у методології на рівні світу - Платформа зеленого зростання (Green Growth Knowledge.org).

1.Сталий розвиток - XXI століття: управління, технології, моделі: колективна монографія / М. Ф. Аверкина, Н. М. Андрєєва, М. Д. Балджи, О. О. Веклич та ін. НАН України, ДУ «Інститут економіки природокористування та сталого розвитку НАН України»; НТТУ «Київський політехнічний інститут»; Вища економіко-гуманітарна школа; Міжнародна асоціація сталого розвитку ; за наук. ред. проф. Хлобистова Є.В. Черкаси: Видавець Чабаненко Ю. А., 2014. С. 170-181. 2. Войціховська А., Кравченко О., Мелень-Забрамна О., Панькевич М. Кращі європейські практики управління відходами : посібник / за заг. ред. О. Кравченко. Львів : Видавництво «Компанія “Манускрипт"», 2019. 64 с. 3. Про внутрішнє і зовнішнє середовище в Україні у 2013 році: щорічне послання Президента України до Верховної Ради України. К. : НІСД, 2013. 576 с. 4. Державна служба статистики України. URL: http://www.ukrstat.gov.ua/ (дата звернення: 03.02.2021).

\section{REFERENCES:}

1. Stalyi rozvytok - KhKhl stolittia: upravlinnia, tekhnolohii, modeli : kolektyvna monohrafiia / M. F. Averkyna, N. M. Andrieieva, M. D. Baldzhy, 0. 0. Veklych ta in. NAN Ukrainy, DU «Instytut ekonomiky pryrodokorystuvannia ta staloho rozvytku NAN Ukrainy»; NTTU «Kyivskyi politekhnichnyi instytut»; Vyshcha ekonomiko-humanitarna shkola; Mizhnarodna asotsiatsiia staloho rozvytku; za nauk. red. prof. Khlobystova Ye. V. Cherkasy : vydavets Chabanenko Yu. A., 2014. S. 170-181. 2. Voitsikhovska A., Kravchenko 0., Melen-Zabramna 0., Pankevych M. Krashchi yevropeiski praktyky upravlinnia vidkhodamy : posibnyk / za zah. red. O. Kravchenko. Vydavnytstvo Lviv : «Kompaniia "Manuskrypt"», 2019. 64 s. 3. Pro vnutrishnie i zovnishnie seredovyshche v Ukraini u 2013 rotsi: shchorichne poslannia Prezydenta Ukrainy do Verkhovnoi Rady Ukrainy. K. : NISD, 2013. 576 s. 4. Derzhavna sluzhba statystyky Ukrainy. URL: http://www.ukrstat.gov.ua/ (data zvernennia: 03.02.2021). 


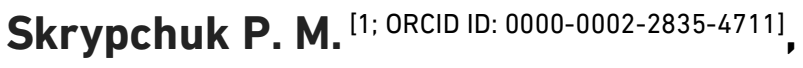
Doctor of Economics, Professor,

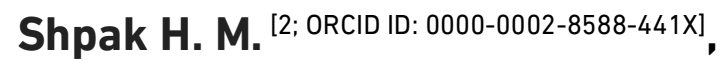
Candidate of Economics (Ph.D.), Trokhliuk T. M. [3; ORCID ID: 0000-0002-8336-8665], Candidate of Economics (Ph.D.)

\author{
${ }^{1}$ National University of Water and Environmental Engineering, Rivne \\ ${ }^{2} S S D$ «Rivne Technical Vocational College» NUWEE, Rivne \\ ${ }^{3} S S D$ «Bereznivsky Forestry Professional College» NUWEE, Berezne, Rivne region
}

\title{
HANDLING OF BY-PRODUCTS IN THE ECONOMY: BUSINESS PROCESSES IN THE CONTEXT OF EUROPEAN INTEGRATION
}

World best practices and institutions (UN, UNIDO and UNEP) believe that resource-efficient and cleaner production is the path to a circular economy and waste management. Harmonization of laws and standards in Ukraine involves the use of preventive strategies for all types of waste that increase the efficiency of the economy, form social and environmental significance. The article is devoted to waste prevention and waste management and corresponds to the Directive 2008/98 / EC on waste to be produced in Ukraine by: reducing the amount of waste, reducing the adverse effects of waste on the environment and human health; implementation of the National Waste Management Strategy in Ukraine until 2030. Promising for Ukraine are: sorting of waste with their subsequent processing; formation of online plans for waste collection and logistics; certain types of toxic and medical waste management; prevention of waste incineration and disposal of only a part of waste that cannot be recycled. One of the options for digitalization of waste management can be a tool - information and communication platforms in the regions (communities) in the methodology at the global level which is the Platform for Green Growth. Proposals for harmonization of legal and regulatory documents in the field of environmental management should be considered in two aspects: long-term and short-term. The long-term aspect of the concept is related to the desire to form in the future a theoretically sound and practically effective mechanism for internalizing external costs, as well as ensuring environmentally safe and economically feasible development. The shortterm aspect is designed to consolidate in legislative and regulatory form the international experience of greening the country's economy in order to protect the environment from the negative anthropogenic impact.

Keywords: solid household waste; handling of by-products; economic efficiency; business processes; European integration. 
Скрипчук П. М. ${ }^{[1 ;}$ ORCID ID: 0000-0002-2835-4711],

д.э.н., профессор,

Шпак Г. М. [2; ORCID ID: 0000-0002-8588-441X],

К.Э.H.,

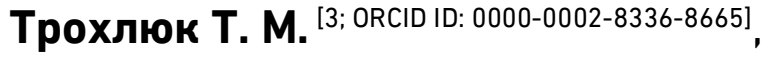

К.Э.H.

${ }^{1}$ Национальный университет водного хозяйства и природопользования, г. Ровно

${ }^{2} О С П$ «Ровенский технический профессиональный колледж» НУВХП, г. Ровно,

${ }^{3} О С П$ «Березновский лесотехнический профессиональный колледж» НУВХП.,

г. Березно, Ровенской обл.

\section{ОБРАЩЕНИЕ С ПОБОЧНЫМИ ПРОДУКТАМИ В ЭКОНОМИКЕ: БИСНЕС-ПРОЦЕССЫ В КОНТЕКСТЕ ЕВРОИНТЕГРАЦИИ}

Лучшие мировые практики и институты (ООН, ЮНИДО и ЮНЕП) считают, что ресурсно-эффективное и более чистое производство это путь к циркулярной экономики и обращения с отходами. Гармонизация законов и стандартов в Украине предусматривает использование превентивных стратегий поведения со всеми видами отходов, которые повышают эффективность экономики, формируют социальную и экологическую значимость. Перспективными для Украины: сортировка отходов с последующей их переработкой; формирования онлайн планформ сбора и логистики отходов; отдельные виды обращения с токсичными медицинскими отходами; запрет сжигания отходов и захоронения лишь доли отходов которых невозможно переделать. Одним из вариантов диджитализации сферы обращения с отходами может быть инструмент - информационно-коммуникативные платформы в регионах (общинах) в методологии на уровне мира - Платформа зеленого роста.

Ключевые слова: твердые бытовые отходы; обращения с побочными продуктами; экономическая эффективность; бизнес-процессы; евроинтеграция. 